\title{
Evidence of a further emerging threat to lion conservation; targeted poaching for body parts
}

\author{
K. T. Everatt ${ }^{1,2,3,4}$ D $\cdot$ R. Kokes ${ }^{3} \cdot$ C. Lopez Pereira ${ }^{5}$
}

Received: 17 May 2019 / Revised: 21 August 2019 / Accepted: 9 October 2019 / Published online: 15 October 2019 (C) The Author(s) 2019

\begin{abstract}
The African lion, Panthera leo, has, like many of the world's megafauna, become threatened with extinction over the past century. Loss of habitat and prey, persecution in retaliation of livestock depredation, by-catch by bushmeat poachers and unsustainable trophy hunting are all documented anthropogenic caused threats to lion conservation. Here we present data that indicate the emergence of a further threat to lion conservation: the targeted poaching of lions for body parts. We present lion abundance and mortality data from field surveys in southern Africa between 2011 and 2018 of a resident lion population. The targeted poaching of lions for body parts accounted for $35 \%$ of known human caused mortalities across the landscape and $61 \%$ of mortalities within Limpopo National Park with a clear increase in this pressure in 2014. Retaliatory killing for livestock conflict accounted for $51 \%$ of total mortalities, however in $48 \%$ of conflict cases body parts were also removed, suggesting that a demand for body parts may incentivize conflict related killing of lions. The use of poison was the most common means of killing lions and was recorded in $61 \%$ of mortalities. Teeth and claws were the body parts harvested most often from illegally killed animals in the study area, with an increase from 2014 onwards. This pressure threatens the viability of the species in our study area and the success of current conservation initiatives. We suggest that the results of this study be viewed as a warning to the global conservation community to be vigilant of the impact that illegal wildlife trade can have on the conservation of lions, just as a similar pressure has already had on other big cat populations.
\end{abstract}

Keywords Illegal wildlife trade $\cdot$ Lion bones $\cdot$ Poison $\cdot$ Conservation $\cdot$ Africa $\cdot$ Panthera leo $\cdot$ Livestock conflict $\cdot$ Mozambique $\cdot$ Snaring $\cdot$ Bushmeat $\cdot$ Trap $\cdot$ IWT $\cdot$ Kruger National Park $\cdot$ Limpopo National Park $\cdot$ Call-up surveys $\cdot$ Anti-poaching

Communicated by Karen E. Hodges.

This article belongs to the Topical Collection: Biodiversity exploitation and use.

Electronic supplementary material The online version of this article (https://doi.org/10.1007/s1053 1-019-01866-w) contains supplementary material, which is available to authorized users.

K. T. Everatt

keveratt@panthera.org

Extended author information available on the last page of the article 


\section{Introduction}

The African lion, Panthera leo, has, along side many of the world's megafauna, become threatened with extinction over the past century (Ripple et al. 2014; Bauer et al. 2015a). Lion populations are estimated to have declined by approximately $43 \%$ over the past 21 years (Bauer et al. 2015b) with an estimated 32,000 remaining across Africa, while lion range has declined by $75 \%$ over the past 50 years (Riggio et al. 2013). Persecution, loss of prey and loss of habitat are the primary drivers of these declines (Bauer et al. 2015 b). Lions are regularly killed in retaliation of livestock depredation, a pressure that is expected to rise with Africa's growing cattle herds (IUCN 2006; Hazzah et al. 2014). Widespread illegal bushmeat hunting is responsible for decimating prey populations across Africa, thus reducing habitat suitability for lions (Lindsey et al. 2013) as well as impacting lions directly through mortalities as by-catch in wire snares set for prey species (Becker et al. 2013). Unsustainable trophy hunting limits lion populations (Loveridge et al. 2007) and can cause population declines (Packer et al. 2009). In addition to each of these well documented drivers of lion population declines, the targeted poaching of lions for body parts for illegal wildlife trade (IWT) may emerge as yet another significant threat to the viability of lions, as it has for several other big cat species (Environmental Investigations Agency 2017). IWT is the estimated to be the fifth largest illegal industry globally, valued between US\$5 and US\$20 billion per year (Dudley et al. 2013; Wyler and Sheikh 2008). The trade ranges from small scale hunting in localised areas to commercial, transnational trafficking, both of which have major repercussions for targeted species conservation (Biggs et al. 2016). For example, the targeted poaching of tigers (Panthera tigris) for bones and skins is one of the most significant threats to tiger population viability (Chapron et al. 2008; Dinerstein et al. 2007; Goodrich et al. 2008), as is the poaching of leopards (Panthera pardus) for skins (Swanepoel et al. 2016; Raza et al. 2012), the poaching of snow leopards (Panthera uncia) for skins and bones (Hussain 2003; Li and Lu 2014) and the poaching of jaguars (Panthera onca) also for skins and more recently also for their teeth (Verheij 2019).

From 2011 to 2018 we studied the population ecology of lions in the Greater Limpopo Lion Conservation Unit (GLLCU) (IUCN 2006), identified as one of eleven 'lion strongholds' (Riggio et al. 2013). The GLLCU includes South Africa's Kruger National Park, Zimbabwe's Gonarezhou National Park and Mozambique's Limpopo, Banhine and Zinave National Parks (IUCN 2006). We examined changes in abundance and cause of death for lions from the Mozambican portion of the landscape using primary and auxiliary data obtained from camera-trapping, spoor and call-up surveys, satellite GPS collaring exercises (Everatt et al. 2014, 2015, 2019) and information collated from National Park management. Our aim was to improve knowledge of the conservation status of this sub-population and to identify primary threats. Furthermore, we had a priori concerns of an apparent emergence in the targeted poaching of lions in the region and sought to quantify the nature and relative extent of this threat. 


\section{Methods}

\section{Study area and population}

This study reports on data collected from the Mozambican portion of the Greater Limpopo Lion Conservation Unit (GLLCU) including Limpopo National Park (LNP)

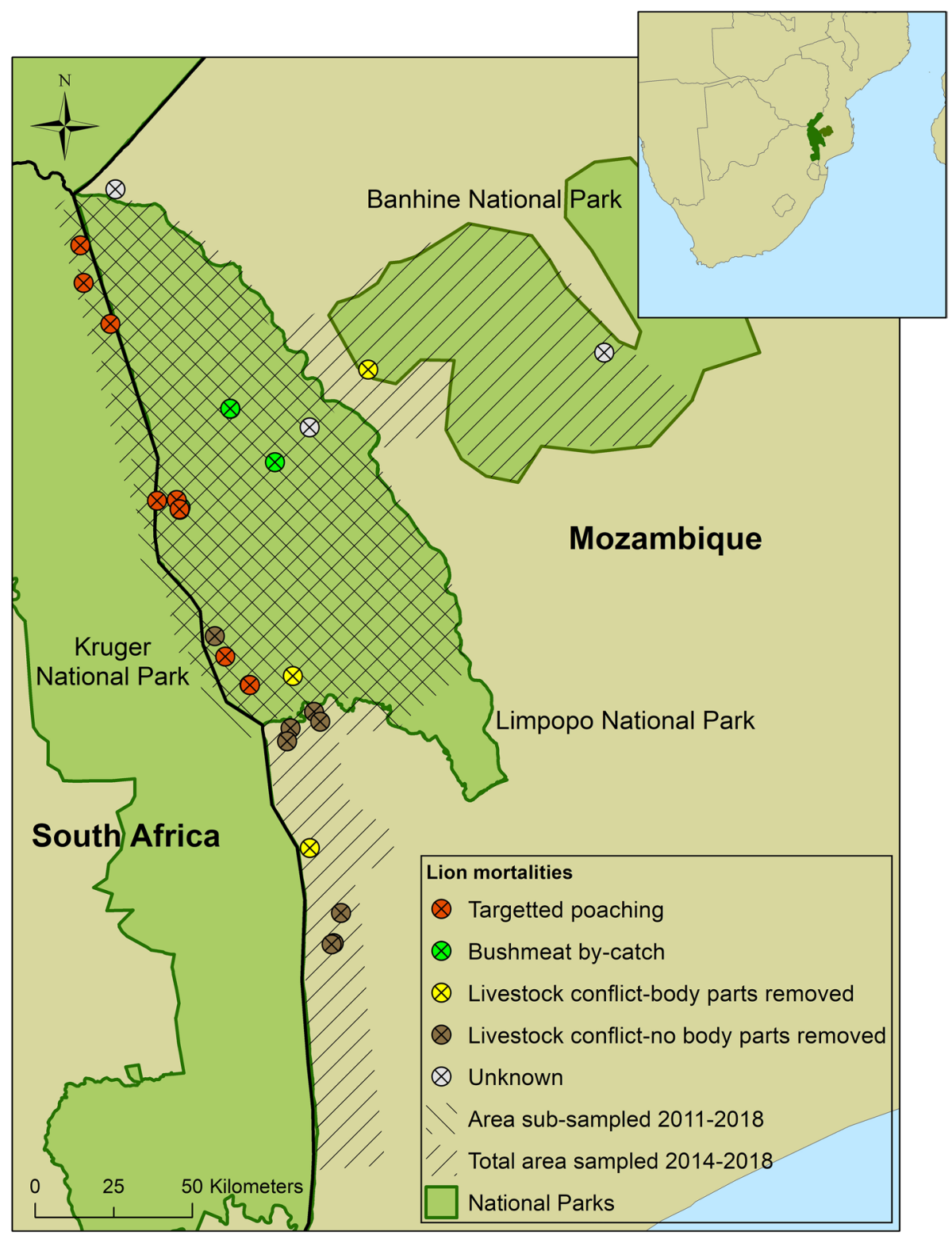

Fig. 1 Study area and locations of mortality events 
$\left(11,233 \mathrm{~km}^{2}\right)$, Banhine National Park (BNP) $\left(7250 \mathrm{~km}^{2}\right)$ and adjacent community lands, as well as the boundary area of South Africa's Kruger National Park (KNP) (Fig. 1). The region consists of open woodland savannah, bushlands and wetlands (Stalmans et al. 2004). LNP includes 18 communities with a human population of approximately 7000 in the central park and a further 20,000 in the buffer zone (Massé 2016). Approximately 36,000 cattle (Bos primigenius) graze within the park (Grossmann et al. 2014) with higher numbers outside. BNP includes two communities and 3000 residents within the boundaries (http://www.biofund.org.mz/en/database/platform-of-the-conservati on-areas/) grazing at least 500 cattle (Stalmans and Peel 2012), and a near continuous band of communities with livestock along its edges (Everatt et al. 2015). LNP and BNP are each impacted by widespread subsistence and commercial poaching for wild meat (bushmeat) and commercial poaching for elephant ivory and rhino horn (Everatt et al. 2014; Grossmann et al. 2014: Everatt et al. 2019). Overall wildlife densities in both Mozambican parks are well below carrying capacity following high losses of larger species during years of war between 1964 and 1992 and subsequent years of overexploitation for meat, ivory and rhino horn (Hatton et al. 2001; Baghai et al. 2018). However, removal of portions of the South Africa-Mozambique border fence as part of the creation of the Greater Limpopo Trans-Frontier Park (2000) provided the opportunity for re-colonization of wildlife into LNP from neighbouring Kruger National Park (KNP) (Hanks 2000). KNP contains no cattle, has relatively high levels of wildlife protection and supports lion and other wildlife at or near carrying capacity (Lindsey et al. 2017), consequently KNP likely acts as natural source habitat for many species in LNP. In addition, approximately 4500 ungulates have been translocated from KNP to LNP between 2011 and 2014 (LNP management).

\section{Study design}

Between October 2011 and December 2018, we collected data on the population status of, and causes of mortalities faced by, the lion sub-population in the Mozambican GLLCU and conducted intensive monitoring of individual lion prides in LNP.

\section{Lion abundance}

In order to estimate current lion abundance in LNP we conducted a near-repeat (87\% of the same sample sites) lion call-up survey in 2017 of a published call-up survey conducted in 2012 (Everatt et al. 2014). A total of 47 sites were sampled in September and October 2017. Assuming a detection radius of $3.7 \mathrm{~km}$ (Ferreira and Funston 2010) the total sampling effort covered approximately $2021 \mathrm{~km}^{2}$ or $30 \%$ of the $6708 \mathrm{~km}^{2}$ potential lion habitat in LNP [calculated by excluding a $2 \mathrm{~km}$ buffer around cultivated areas (Everatt et al. 2014)]. At each sampling site, the distress call of a buffalo calf was broadcast from loudspeakers (https://www.primos.com/products/predator-calls/alpha-dogg/) for repeated sessions of five minutes on and five minutes off for one hour. Approaching carnivores were detected using night vision equipment (http://bushnell.com/tactical/night-vision/6x-50mmequinox-z) and numbers, sex and age classes were recorded. Sites were located approximately $5 \mathrm{~km}$ apart, beginning from a random starting point. Specific locations for sites $(+1 \mathrm{~km})$ were chosen based on relative visibility and presence of linear features or habitat edges such as roads, trails and rivers, which might be used by lions. Sampling was conducted between 18:00 and 22:00 or 04:00 and 06:00 on nights with little or no wind ( $\leq 5$ on 
the Beaufort scale). For the sake of comparison, we also estimated spotted hyena (Crocuta Crocuta) abundances in LNP from both call up surveys using published response probabilities (Mills et al. 2001).

Minimum counts of lions for BNP were determined from spoor surveys undertaken in 2014 (Everatt et al. 2015) and GPS collaring exercises in 2017 and 2018.

\section{Pride size and structure in LNP}

We monitored lions and estimated minimum pride sizes and structures in LNP during three study periods (September 2011 to November 2012, June 2014 to May 2015 and March 2016 to December 2018) using data from a combination of camera-trapping (2011-2012 and 2016-2018) (Everatt et al. 2014, 2015), call-up surveys (2012 and 2017), GPS collaring exercises and subsequent GPS and VHF tracking (2016-2018) and field observations (2011-2012, 2014-2018).

GPS collaring exercises consisted of similar methods described for call-up surveys with the addition of using bait. Responding lions were immobilised and collared following the Zimbabwe Veterinary Association Wildlife Group standard operating procedures (Kock and Burroughs 2014). Procedures were reviewed and approved by the Animal Research Ethics Committee at Nelson Mandela University (ethics approvals A13-SCI-ZOO-014, A18-SCI-ZOO-007) and approval for capturing and handling of lions was granted by the Administração Nacional das Áreas de Conservação (ANAC) of Mozambique (permits 005-2016, 001-2017, 006-2018). Lions were free darted using a Dan-inject JM dart gun (Dan-inject RSA, Skukuza, South Africa). Male lions were administered with approximately 80-100 mg Zooletil ${ }^{\circledR}$ and 6-8 mg medetomidine and reversed with $5 \times$ medetomidine dose of atipamazole, and female lions were administered with approximately $80 \mathrm{mg}$ Zooletil ${ }^{\circledR}$ with 4-6 mg medetomidine and reversed with $5 \times$ medetomidine dose of atipamezole (Kock and Burroughs 2014). All lions were immobilized by a qualified veterinarian or by KTE who was trained and qualified by the Zimbabwe Veterinary Association Wildlife Group and working under supervision of CLP and ANAC. Lions were fitted with satellite GPS collars (VECTRONIC Aerospace, Berlin, Germany; African Wildlife Tracking, Pretoria, South Africa) which were programmed to record locations every $2 \mathrm{~h}$ between 18:00 and 6:00 and one location at 12:00, all available for download twice a day. Collars also transmitted VHF signal. Individual lions were then relocated and followed using GPS and VHF tracking. Minimum pride size and structure was recorded from direct observations and camera trap images. Individual lions were identified using whisker spot patterns and other physical distinguishing features i.e. scars, ear notches and manes (Pennycuick and Rudnai 1970).

We tested for significance in changes of the average minimum pride size and average number of adult females in each of our focal study prides between 2012 and 2018 using a paired $t$-test assuming unequal variances and calculated the average percentage declines.

\section{Lion mortality}

We collated all available data on lion mortalities across the study area between 2011 and 2018. Data was gathered as auxiliary data during camera-trapping surveys, spoor surveys, GPS collaring exercises and from field observations (Everatt et al. 2014, 2015, 2019; Everatt 2016, Everatt unpublished). Data was also gathered from information reported to the PI by National Parks and reserve management, and from anti-poaching 
patrols. Mortality data collected included cause of death, such as natural, snared, trapped, poisoned, or shot and when possible the motive behind the killing including in retaliation of livestock conflict, bushmeat poaching by-catch, or targeted poaching. We defined the targeted poaching of lions as a human caused mortality event where there was (1) no evidence of human-lion conflict i.e. incident far from livestock/village areas and, (2) there was evidence of deliberate attempts to kill lions, i.e. bait (meat) laid with poison and / or bait surrounded by snares and, (3) the body parts were removed. Using these criteria, we were able to distinguish between poaching events which were targeting lions and poaching events where lions were killed but were not the target species.

In order to reduce bias associated with the variation in study area coverage between 2011 and 2012 (approximately $8000 \mathrm{~km}^{2}$ ) (Everatt et al. 2014), $2013\left(11,000 \mathrm{~km}^{2}\right.$ ), and 2015-2018 (approximately 16,000 km²) (Everatt et al. 2015, 2019) we presented all data on annual mortality sources, means and body parts removed as percentages of yearly documented totals (Figs. 2, 3, 4). We also present a subset of mortality type data for LNP and the immediate areas of KNP (within $<6 \mathrm{~km}$ of border) (approximate total area $8000 \mathrm{~km}^{2}$ ). We tested whether the frequencies of targeted poaching for body parts and the frequencies of retaliatory killing for livestock conflict with body parts removed were

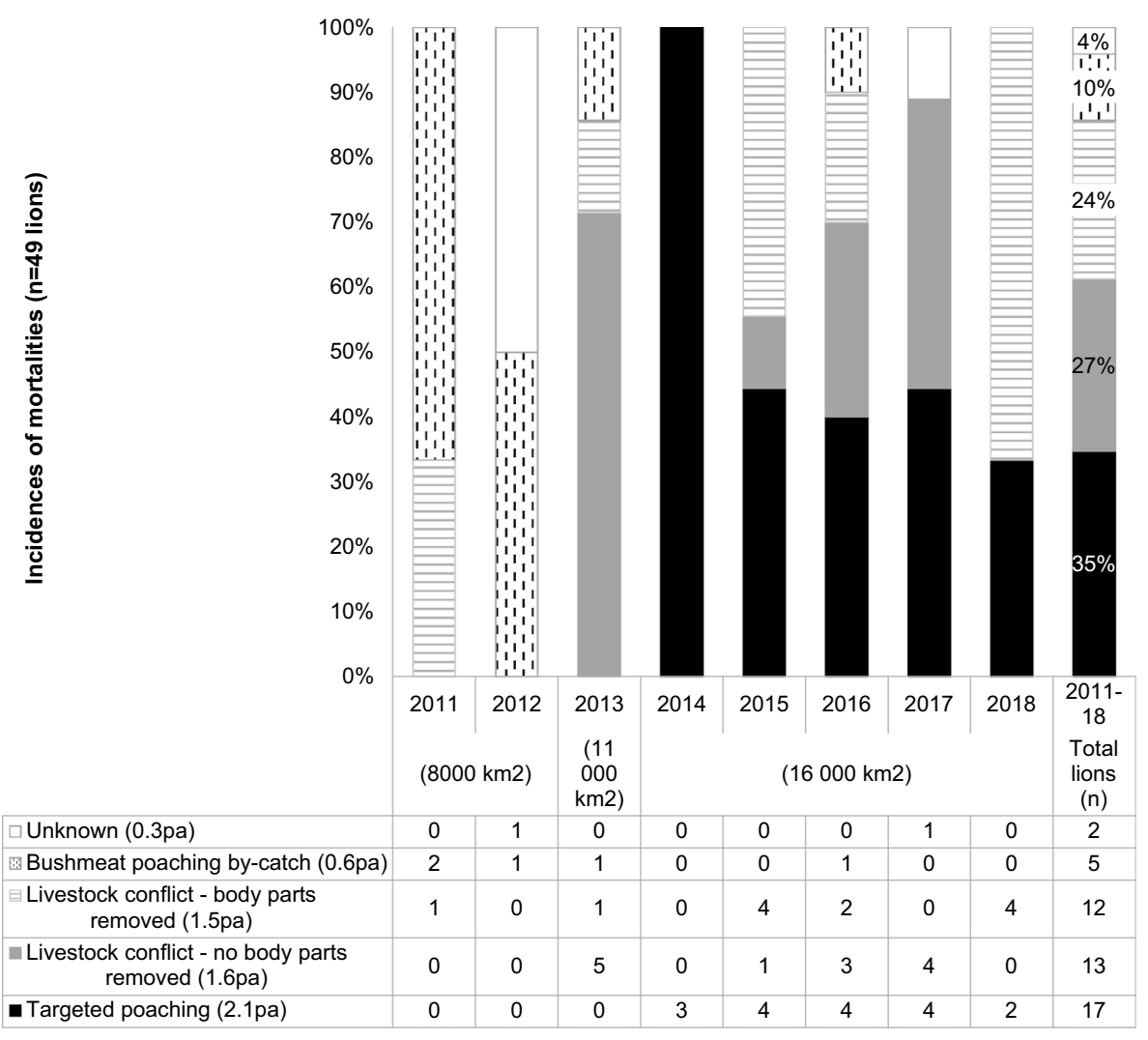

Fig. 2 Incidences of different types of human caused lion mortalities (2011-2018). Data was collected continuously from the initial $8000 \mathrm{~km}^{2}$ area from 2011 to 2018 . This area was then increased to $11,000 \mathrm{~km}^{2}$ in 2013, and to $16,000 \mathrm{~km}^{2}$ in 2014 


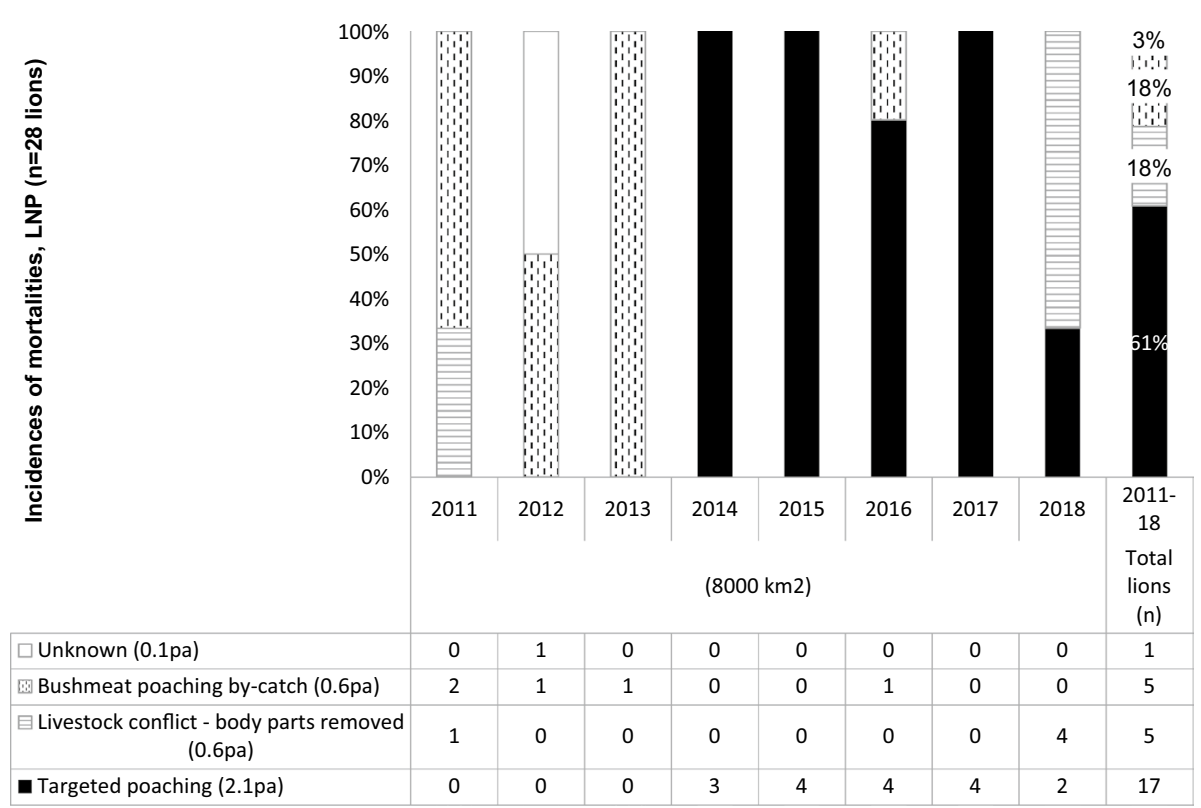

Fig. 3 Incidences of different types of human caused lion mortalities, LNP and immediately adjoining areas (2011-2018). Data was collected continuously from this initial $8000 \mathrm{~km}^{2}$ area, including immediate areas of KNP, from 2011 to 2018

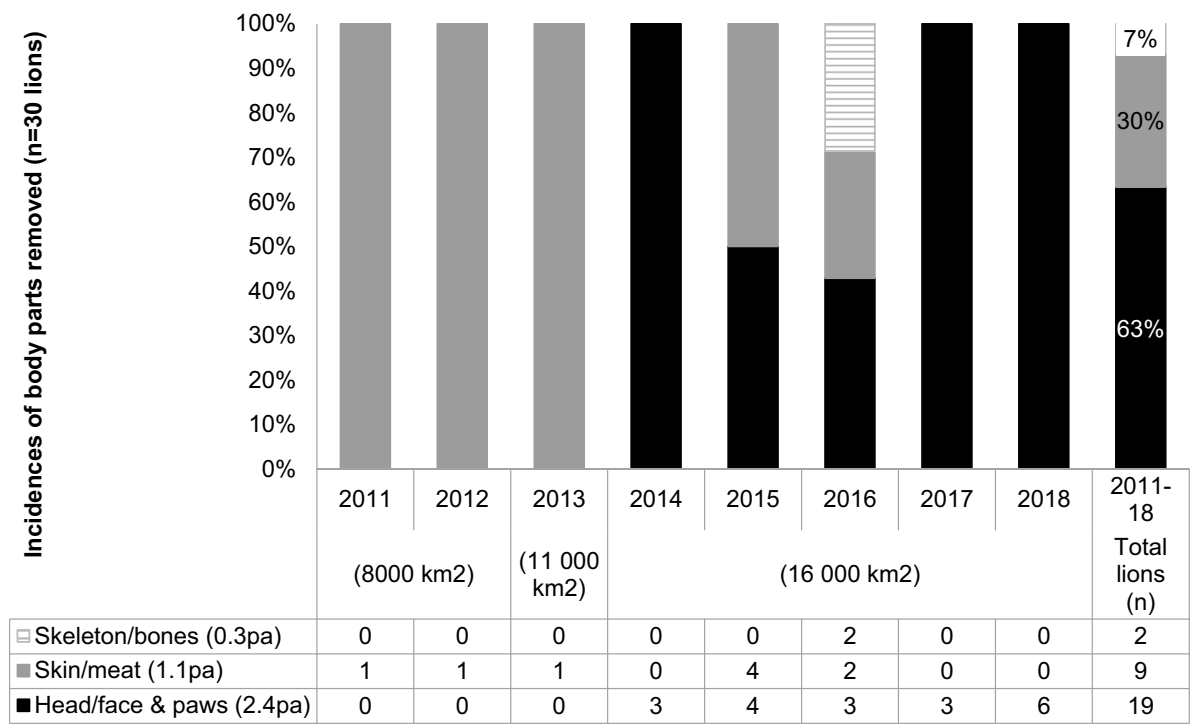

Fig. 4 Body part types removed from illegal killed lions (2011-2018). Data was collected continuously from the initial $8000 \mathrm{~km}^{2}$ area from 2011 to 2018 . This area was then increased to $11,000 \mathrm{~km}^{2}$ in 2013 , and to $16000 \mathrm{~km}^{2}$ in 2014 
correlated by calculating a Pearson's correlation coefficient. All analyses were done in MS Excel v. 1906.

In addition, we collated available information on the illegal wildlife trade of lions in Mozambique. This included information on specific lion body parts being traded and on the possible destinations for these illegal body parts. These data were provided by the by the Mozambican Administrator of National Conservation Areas.

\section{Results}

\section{Changes in lion abundance in LNP}

During the 2017 survey of LNP a total of three lions, two adult males and one adult female, responded at two of 47 call-up stations, giving a mean of 0.06 lion responses per station. Considering a probability of response obtained from calibration experiments in adjoining KNP (Ferreira and Funston 2010), a total population estimate of 22.1 lions or a density of 0.33 lions $/ 100 \mathrm{~km}^{2}$ was calculated for LNP in 2017 (due to a low response rate we were unable to calculate variance). A population estimate for LNP obtained from the 2012 callup survey gave an estimate of 66.2 animals or a density of 0.99 lions $/ 100 \mathrm{~km}^{2}$ (Everatt et al. 2014). These differences in population estimates indicate a $66 \%$ decline in lion abundance in LNP between 2012 and 2017. In comparison spotted hyena had a mean response per station of 0.42 in 2012 and 0.41 in 2017 with estimated abundances of 105 hyenas in LNP in 2012 and 100 in 2017, indicating a relatively stable population (-4\%).

\section{Changes in focal pride size and structure}

Six resident prides were first identified in LNP in 2012 and two more prides were identified in BNP in 2015. Attempts were made to fit GPS collars on one animal from each identified pride during 2016-2018. A total of seven lions from four prides were fit with GPS

Table 1 Adult female estimates, minimum pride sizes and known mortalities of focal study prides in LNP

\begin{tabular}{|c|c|c|c|c|c|c|c|c|c|}
\hline \multirow{2}{*}{$\begin{array}{l}\text { Pride } \\
\text { Year }\end{array}$} & \multicolumn{3}{|l|}{ Maleni } & \multicolumn{3}{|c|}{ Machampane } & \multicolumn{3}{|c|}{ Shingwedzi } \\
\hline & Adult F & Pride size & Killed & Adult F & Pride size & Killed & Adult F & Pride size & Killed \\
\hline 2011 & 3 & 5 & 1 & UK & UK & UK & UK & UK & UK \\
\hline 2012 & 3 & 5 & 0 & 3 & 5 & 1 & 3 & 4 & 0 \\
\hline 2013 & - & - & 1 & - & - & - & - & - & - \\
\hline 2014 & - & - & - & - & - & 3 & - & - & - \\
\hline 2015 & - & - & - & - & - & - & - & - & - \\
\hline 2016 & UK & UK & UK & 1 & 2 & 2 & 5 & 11 & 3 \\
\hline 2017 & 1 & 1 & 0 & 1 & 5 & 2 & 0 & 2 & 5 \\
\hline 2018 & 1 & 2 & 0 & 0 & 3 & 6 & 0 & 2 & 0 \\
\hline Average & 2 & 3.25 & 0.4 & 1.25 & 3.75 & 2.8 & 2 & 4.75 & 2 \\
\hline Total killed & - & - & 2 & - & - & 14 & - & - & 8 \\
\hline$\%$ decline & 66.7 & 60 & - & 100 & 40 & - & 100 & 50 & - \\
\hline
\end{tabular}


collars in LNP and two lions from one pride in BNP. One entire pride in BNP was killed in December 2015 and from 2016 to 2018 we were unable to find sign of one entire pride in LNP which are assumed to have also been killed. Of these known original eight prides we were able to regularly monitor the pride size and structure of three prides in LNP. The average minimum pride size from these focal prides was $3.25,3.75$ and 4.75 across the study period (Table 1 ). The average minimum pride size was significantly smaller in $2018(\mathrm{M}=2.33, \mathrm{SD}=0.33)$ than in $2012(\mathrm{M}=4.67, \mathrm{SD}=0.33)(\mathrm{t}=4.95, \mathrm{p}=0.01)$ with $50 \%$ decline in the average pride size (Table 1). The average estimated number of adult females was 2, 1.5 and 2 for each of the three focal study pride across the study period (Table 1). However, the number of adult females was significantly lower in $2018(\mathrm{M}=0.33$, $\mathrm{SD}=0.33)$ than $2012(\mathrm{M}=3.00, \mathrm{SD}=0.00) ; \mathrm{t}=8.00, \mathrm{p}=0.02$ with an $89 \%$ decline in the average number of adult females per pride. The sex ratio among the focal study pride adults decreased from 1.8 females: 1 male to 0.25 females: 1 male during the same period (Supplementary information). During the time this paper was being prepared the last three known members of the Machampane pride were poisoned (July 2019).

\section{Lion mortality}

We documented 49 lion deaths caused by humans across the study area during the entire study period (Fig. 2). The proportion of demographics of killed lions included: adult females 0.10 (95\% CL $0.03 \pm 0.22$ ), adult males 0.18 (95\% CL $0.09 \pm 0.32$ ), sub adult females 0.08 (95\% CL $0.02 \pm 0.10$ ), sub adult males 0.33 (95\% CL $0.20 \pm 0.48$ ), and unknowns 0.30 (95\% CL $0.18 \pm 0.45)$ (incidents where carcasses had decomposed to such an extent that sexing and ageing were not possible). This included 22 lion mortalities from the three focal study prides ( 6 adult females, 9 adult males, 2 sub adult females, 6 sub adult males) (Table 1, Supplementary information). Between 2014 and 2017, five lions of two identified resident prides in BNP were also killed. This followed a single livestock conflict incident, which saw all four members from one pride killed. A collared lioness from the second resident pride was then killed through targeted poaching in 2017.

The targeted poaching of lions for body parts accounted for 0.35 (95\% CL $0.22 \pm 0.5$ ) proportion of known human caused mortalities across the landscape (Fig. 2) and 0.61 $(0.40 \pm 0.79$ of human caused mortalities in LNP and immediately adjoining areas (Fig. 3). Retaliatory killing for livestock conflict accounted for $0.51(0.36 \pm 0.66)$ proportion of mortalities across the landscape and $0.18(0.06 \pm 0.4)$ of mortalities in LNP and immediately adjoining areas (Fig. 3), however in $0.48(0.28 \pm 0.69)$ proportion of all lion-livestock conflict cases body parts were also removed from the lions. Bushmeat poaching by-catch accounted for $0.10(0.03 \pm 0.22)$ proportion of lion mortalities across the study area (Fig. 2) and $0.18(0.06 \pm 0.37)$ proportion of mortalities in LNP and immediately adjoining areas (Fig. 3). Across the study area $0.59(0.44 \pm 0.73)$ proportion of recorded mortalities had body parts removed (Fig. 2). In 2014 we recorded the first incident of targeted lion poaching and since 2014 we have recorded an average of 2.1 lions killed through targeted poaching annually (Fig. 2). We found no statistical correlation between the prevalence of targeted poaching and retaliatory killings where body parts were removed for the entire study period and post $2014(r=0.29, \mathrm{p}>0.05$ and $r=-0.27, \mathrm{p}>0.05)$.

The body parts removed from lions included, heads or faces and paws in 0.66 $(0.46 \pm 0.82)$ proportion of cases, meat or skin in $0.31(0.15 \pm 0.51)$, and skeletons or bones in $0.07(0.01 \pm 0.22)$ (Fig. 4). There was a noticeable shift over the study period in the types of body parts being removed, with the skin and meat being the 


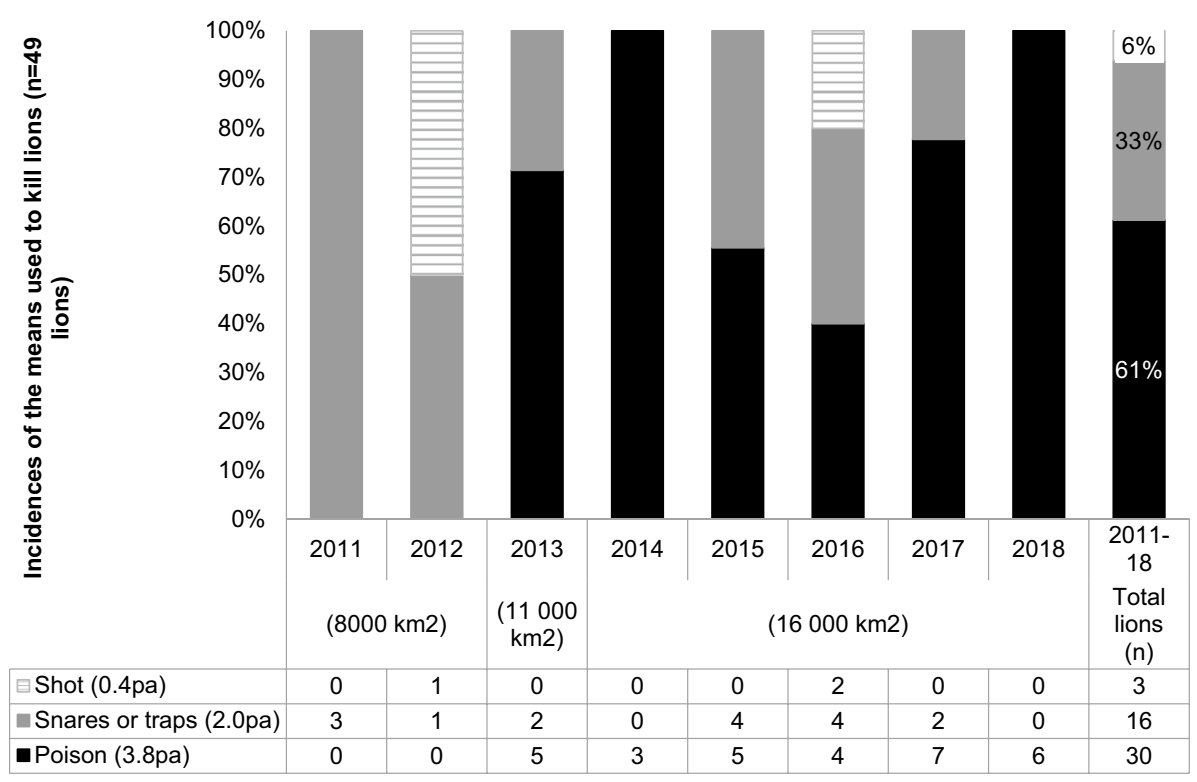

Fig. 5 Methods used to illegally kill lions (2011-2018). Data was collected continuously from the initial $8000 \mathrm{~km}^{2}$ area from 2011 to 2018 . This area was then increased to $11,000 \mathrm{~km}^{2}$ in 2013 , and to $16,000 \mathrm{~km}^{2}$ in 2014

only recorded parts taken prior to 2014 and then from 2014 onwards heads or faces and paws accounted for the majority of the body parts moved (Fig. 4). Skeletons were taken from two lions in 2017 (Fig. 4). Of all recorded deaths $0.61(0.46 \pm 0.75)$ proportion of the lions were poisoned, $0.33(0.20 \pm 0.48)$ were snared or trapped and 0.06 $(0.01 \pm 0.17)$ were shot (Fig. 5). There was a noticeable increase in the use of poison to kill lions from 2013 onwards (Fig. 5). All targeted lion poaching events involved lions being killed with poisoned meat and or killed in baited snares or traps. Wild ungulates were used as bait in $0.63(0.38 \pm 0.84)$ proportion of targeted poaching incidents and the remains of poached elephants were used as bait in $0.37(0.16 \pm 0.62)$ of incidents (Supplementary information).

\section{Destination of confiscated body parts}

We recorded reports of four cases where lion body parts were confiscated in Mozambique between 2013 and 2017. Of these known cases, canine teeth and claws were confiscated twice, skin, meat and fat once and a full skeleton once. Both shipments of teeth and claws were confiscated by Mozambican government authorities in 2016 at an international airport and were destined for Vietnam, with one of the seizures including a combination of lion parts and elephant ivory. A lion skeleton was confiscated by LNP authorities during 2016 and destined for the capital city, Maputo, with the final destination unknown. The skin, meat and fat were discovered by KTE in 2013 and were being sold locally for traditional medicinal use. 


\section{Discussion}

This study presents data indicating the emergence of a further threat to lion conservation - the targeted poaching of lions for body parts. This threat has the potential to have devastating impacts on lion populations mirroring the effects similar pressures have had on wild tiger populations (Chapron et al. 2008; Dinerstein et al. 2007; Goodrich et al. 2008) and may be having on jaguar populations (Verheij 2019).

In our study area, the targeted poaching of lions for body parts has likely contributed unsustainable rates of mortality and has become a direct threat to the viability of lions. These data clearly describe an important yet lesser known, additive threat to the conservation of wild lions and presents a novel contribution to the science of ecological responses of apex predators to changing anthropogenic pressures.

We estimated that the lion population of Limpopo National Park has declined by approximately $66 \%$ over 5 years. We acknowledge that due to low responses to call-up surveys the possible influence of stochastic variation cannot be dismissed as explanatory for the differences in the estimates of lion abundance in LNP between 2012 and 2017. However, we believe the additional data collected during the same period from the monitoring of focal study prides including a documented (i) $50 \%$ decline in the average minimum pride size, (ii) $89 \%$ decline in the minimum number of adult females per pride and (iii) change in the pride's average sex ratios from 1.8 to 0.3 females per male in addition to the number of lions we documented killed within these pride's home ranges, all provide additional evidence of a catastrophic decline in the abundance of lions in LNP.

The targeted poaching of lions accounted for 35\% of known human caused mortalities across the landscape and $61 \%$ of lion mortalities in and immediately adjoining Limpopo National Park, far surpassing the combined effects of retaliatory killings of lions following livestock conflict events and deaths associated with by-catch from bushmeat poaching. We did not find a correlation between the targeted poaching of lions for body parts and retaliatory killings where body parts were harvested, suggesting body parts are taken opportunistically during the later. However, a new or rising demand for lion body parts could exacerbate motives to kill lions in the vicinity of communities and livestock, irrespective of livestock losses or a perceived threat of losses. Incentivizing the killing of lions by a demand for body parts could seriously undermine conflict mitigation efforts.

The impacts of these deaths on the lion population would extend beyond a simple decrease in abundance depending on the demographics of the lions killed. For instance, we recorded that in at least one case, and likely two cases, the entire pride of lions was killed, and six adult females were killed from the three focal study prides. The loss of adult pride members can disrupt pride structure and social cohesion, negatively impacting territorial defence and cub recruitment reducing population's ability to withstand possible population disturbances (Loveridge et al. 2007, 2016). The loss of an entire pride or the loss of several or all of the breeding females from a pride can therefore have disproportionate impact on the viability of the sub-population compared to the loss of young dispersing males or females. As cooperative breeders, the reproductive success of a pride increases when three to ten lionesses are present, while female survival is reduced within prides containing only one to two lionesses (Packer et al. 1988). By the end of 2018 two of our three focal study prides had lost all of their adult lionesses. During 2017 and 2018 we documented the last surviving adult lioness from either of the three focal prides twice attempt to raise cubs. Both attempts were unsuccessful. The death of adult pride males also can have cascading 
effects by resulting in a more rapid turnover of pride males and consequent infanticide of cubs (Whitman et al. 2004), with greater detrimental effects to the population.

The cause of the increase in targeted poaching of lions for body parts is still poorly understood. A local demand for traditional medicinal or ceremonial use of lion parts has likely been present in the area for some time. Skin, meat and possibly fat were the only body parts known to be harvested from lions killed from 2011 to 2013, (Fig. 4). These particular killings were non-targeted poaching incidents (Fig. 2) and therefore the harvesting of body parts may have been opportunistic. Fat has been documented as the most prevalent lion derivative in some known muti markets in southern Africa (Williams et al. 2015). The harvesting of heads or faces and paws was first recorded with the emergence of targeted poaching of lions in 2014 and all subsequent targeted poaching victims have had these body parts removed. The same body parts were also harvested from several retaliatory killings, post 2014. This increase in the removal of heads or faces and paws from lions in and around Limpopo National Park, along with the confiscations of lions' teeth and claws at the Mozambique airport indicates a recent demand specifically for lion canine teeth and claws.

While the findings we present here are among the few quantitative descriptions of targeted poaching of lions for body parts, they do confer with the previous finding of Hazzah and Gudka (2010) who documented a trade in lion parts sold as trinkets to tourists in Kenya. There, predominantly Chinese tourists were fuelling a demand for lion teeth and claws, supplied with lions often killed in conflict situations by Masai herdsmen, while other body parts such as pieces of skin, were sought for local demand. The situation we present from Mozambique may have similarities to the situation documented in Kenya, however the main source of the demand is still speculative. During 2017 there has also been reported increases in the poaching of lions for teeth and claws in the Niassa reserve in northern Mozambique (C. Beggs Niassa Lion Project pers coms) and captive lions in the Limpopo province of South Africa (K. Marnewick Endangered Wildlife Trust pers coms) as well as cases where lions killed for conflict in the Caprivi region of Namibia now also had teeth and claws removed (L. Hansen Kwando Carnivore Project pers coms).

Our findings indicate an apparent preference for teeth and claws, which confer with the Williams et al. (2017b) continental meta-analysis of trade in lion parts. Williams et al. (2017b) concluded that the domestic trade in teeth and claws was high across the continent and likely poses a greater threat to wild lions than an international demand, though the impact of which was generally unknown. However, our findings have indicated a possible international demand from Vietnam impacting this wild population and calls for further detailed investigation. The sudden emergence of this preference around 2014 in the study area may also warrant further examination of IWT and legal trade trends at both a domestic and international level and related socio-economic variables of Mozambique around this time. The role and widespread use of the Internet, and in particular social media, is reported to be further facilitating IWT (Lavorgna 2014) whereby a demand for, or use of, a specific species and / or body part may be shared instantly across a large platform signalling a sudden preference.

The legal export of lion parts from captive lion breeders in South Africa may also fuel an illegal trade in lion body parts to be used within Traditional Chinese Medicine markets or curios (Williams et al. 2017a). While direct evidence linking the legal trade in captive sourced lion parts from South Africa to the targeted poaching of wild lion populations has to date been scant (Williams et al. 2015), there is reasonable concern of a link (CITES 2016; Parliamentary hearings). Lion teeth and claws have the highest monetary value in South Africa's legal market (Williams et al. 2019). In all of the lion poaching incidences we documented where only teeth and claws were taken, the poachers involved were 
working on foot and under at least a nominal threat of being arrested. In such a situation it is likely that poacher's selection for teeth and claws over removing full skeletons is a way of optimizing their return while reducing the costs. It is also possible that established rhino and elephant poaching syndicates and traders already operating in the region have simply added lion parts to their list of illegal wildlife products. This hypothesis is supported by interactions we documented between lion and elephant poaching which included the use of poached elephants as bait to kill lions and a seized shipment containing a mix of elephant ivory with numerous lion teeth and claws destined for Vietnam.

\section{Conclusion}

The illegal wildlife trade poses an unprecedented threat to global wildlife (Rosen and Smith 2010) and poaching is a major threat to many of the world's large carnivores (Ripple et al. 2014). The loss of apex predators can have cascading impacts through lower trophic levels leading to ecological state shifts and ecological collapse (Estes et al. 2011). The loss of charismatic megafauna from protected areas can also result in substantial loss of potential revenue from tourism (Naidoo et al. 2016).

We acknowledge that this study is reporting on small data sets, however we believe they are worthy of reporting and consideration in light of this threat's sudden emergence in the system, the potential impact it may have had on an already limited lion population (Everatt et al. 2014, 2019), and the devastating impact it could have on other lion populations across Africa.

We strongly recommend that African governments, protected area managers, conservation organizations, researchers and the global conservation community be vigilant of and quick acting towards addressing this emergent and serious threat to wild African lions, and other big cats. Stakeholders should adopt holistic and collaborative approaches to preventing and halting the poaching of and trade in the body parts of imperilled cats.

Acknowledgements This work was supported by Grants received by KTE from the Wildlife Conservation Network's Lion Recovery Fund [Grant Number MZ-ACE-01]; National Geographic Big Cats Initiative [Grant Number 916]; Natural Sciences and Engineering Research Council of Canada [Grant Number PGSDZ-487542-2016]; the US Fish and Wildlife Service [Grant Number F17AP00822]; the Wilderness Foundation [Grant Number 01-2015,01-2016]; the Ratel Trust [Grant Numbers 05-2016,01-2018]; Panthera Kaplan Graduate Award [Grant Number 10-2014]; Nelson Mandela University Post Graduate Research Scholarship [Numbers NMU PGRS 2014,2015,2016,2017], University of Pretoria Post Graduate Scholarship [Numbers UPPGS 2012,2013] Elephant's Alive, Biologist Without Borders (Grant No: 2016-01), Wilderness Trust (Grant No. 2014), SATIB Trust and the Wilderness Foundation (Grant No. 2016). We thank the Administração Nacional das Áreas de Conservação, Mozambique and South African National Parks for granting us annual research permits as well as the management of Kruger National Park, Limpopo National Park, Banhine National Park and Karangani Nature Reserve for granting us access to each protected area to conduct research. We would also like to thank the many field rangers in each of the parks and reserves where we have been working who have both assisted with research and who work tirelessly towards the protection of threatened wildlife. We would also like to thank several anonymous reviewers.

Open Access This article is distributed under the terms of the Creative Commons Attribution 4.0 International License (http://creativecommons.org/licenses/by/4.0/), which permits unrestricted use, distribution, and reproduction in any medium, provided you give appropriate credit to the original author(s) and the source, provide a link to the Creative Commons license, and indicate if changes were made. 


\section{References}

Baghai M, Lindsey PA, Everatt K, Madope A (2018) Collaborative management models for conservation areas in Mozambique. Regional Best Practices, Current models in Mozambique and a framework for enhancing partnerships to protect biodiversity assets and promote development. Report for USAID SPEED+

Bauer H, Chapron G, Nowell K, Henschel P, Funston P, Hunter LTB, Macdonald DW, Packer C (2015a) Lion (Panthera leo) populations are declining rapidly across Africa, except in intensively managed areas. Proc Natl Acad Sci 112:14894-14899

Bauer H, Packer C, Funston P, Henschel P, Nowell K (2015b) Panthera leo The IUCN Red List of Threatened Species 2016: e.T15951A115130419. http://dx.doi.org/10.2305/IUCN.UK.2016-3.RLTS.T1595 1A107265605.en. Accessed 25 July 2018

Becker M, McRobb R, Watson F, Droge E, Kanyembo B, Murdoch J, Kakumbi C (2013) Evaluating wiresnare poaching trends and the impacts of by-catch on elephants and large carnivores. Biol Conserv 158:26-36

Biggs D, Cooney R, Roe D, Dublin HT, Allan JR, Challender DWS, Skinner D (2016) Developing a theory of change for a community-based response to illegal wildlife trade. Conserv Biol 31(1):5-12

Chapron G, Miquelle DG, Lambert A, Goodrich JM, Legendre S, Clobert J (2008) The impact on tigers of poaching versus prey depletion. J Appl Ecol 45:1667-1674

Convention on International Trade in Endangered Species (CITES) (2016) Conservation of and the trade in the African lion. CoP17, Committee 1. 29, Johannesburg, South Africa

Dinerstein E, Loucks C, Wikramanayake E, Ginsberg J, Sanderson E, Seidensticker J, Forrest J, Bryja G, Heydlauff A, Klenzendorf S (2007) The fate of wild tigers. AIBS Bull 57:508-514

Dudley N, Stolto S, Elliott W (2013) Wildlife crime poses unique challenges to protected areas. Parks 19:7-11

Environmental Investigations Agency (2017) The lions' share; South Africa's trade exacerbates demand for tiger parts and derivatives. EIA report https://eia-international.org/report/the-lions-share. Accessed 19 Aug 2019

Estes JA, Terborgh J, Brashares JS et al (2011) Trophic downgrading of planet earth. Science 333:301-306

Everatt K (2016) Improving the conservation prospects for lion in the Greater Limpopo Lion Conservation Unit; determining key threats and identifying appropriate solutions. Report to ANAC

Everatt KT, Andresen L, Somers MJ (2014) Trophic scaling and occupancy analysis reveals a lion population limited by top-down anthropogenic pressure in the Limpopo National Park, Mozambique. PLoS ONE 9:e99389

Everatt KT, Andresen L, Somers MJ (2015) The influence of prey, pastoralism and poaching on the hierarchical use of habitat by an apex predator. Afr J Wildl Res Spec Carniv Issue 45:187-196

Everatt KT, Moore JF, Kerley GIH (2019) Africa's apex predator, the lion, is limited by interference and exploitative competition with humans. Global Ecol Conserv (in Press)

Ferreira SM, Funston P (2010) Estimating lion population variables: prey and disease effects in Kruger National Park, South Africa. Wildl Res 37:194-206

Goodrich JM, Kerley LL, Smirnov EN, Miquelle DG, McDonald L, Quigley HB, Hornocker G, McDonald $\mathrm{T}$ (2008) Survival rates and causes of mortality of Amur tigers on and near the Sikhote-Alin Biosphere Zapovednik. J Zool 276:323-329

Grossmann F, Lopes Pereira C, Chambal D, Maluleque G, Bendzane E, Parker N, Foloma M, Ntumi C, Polana NA (2014) Aerial survey of elephant, other wildlife and human activity in Limpopo National Park and the southern extension. Wildlife Conservation Society, New York

Hanks J (2000) The role of Tranfrontier conservation areas in Southern Africa in the conservation of mammalian biodiversity priorities for the conservation of mammalian diversity. Has the Panda had its day?. Cambridge University Press, Cambridge, pp 239-256

Hatton J, Couto M, Oglethorpe J (2001) Biodiversity and war: a case study of Mozambique. Biodiversity Support Program, Washington, D.C.

Hazzah L, Gudka M (2010) Dead in tooth and claw: tourism and the illegal trade in African lion (Panthera leo) parts in Kenya. Living with Lions, Kenya, p 9

Hazzah L, Dolrenry S, Naughton L, Edwards CT, Mwebi O, Kearney F, Frank L (2014) Efficacy of two lion conservation programs in Maasailand, Kenya. Conserv Biol 28:851-860

Hussain S (2003) The status of the snow leopard in Pakistan and its conflict with local farmers. Oryx 37:26-33

International Union for Conservation of Nature (IUCN) (2006) Regional conservation strategy for the lion Panthera leo in Eastern and Southern Africa. IUCN SSC Cat Specialist Group, Yaounde 
Kock MD, Burroughs R (2014) Chemical and physical restraint of wild animals. International Wildlife Veterinary Services, Greyston, p 382

Lavorgna A (2014) Wildlife tracking in the Internet age. Crime Scene 3:5

Li J, Lu Z (2014) Snow leopard poaching and trade in China 2000-2013. Biol Conserv 176:207-211

Lindsey PA, Balme G, Becker M et al (2013) The bushmeat trade in African savannas: impacts, drivers, and possible solutions. Biol Conserv 160:80-96

Lindsey PA, Petracca LS, Funston P et al (2017) The performance of African protected areas for lions and their prey. Biol Conserv 209:137-149

Loveridge AJ, Searle AW, Murindagomo F, Macdonald DW (2007) The impact of sport-hunting on the population dynamics of an African lion population in a protected area. Biol Conserv 134:548-558

Loveridge AJ, Valeix M, Chapron G, Davidson Z, Mtare G, Macdonald DW (2016) Conservation of large predator populations: demographic and spatial responses of African lions to the intensity of trophy hunting. Biol Conserv. https://doi.org/10.1016/j.biocon.2016.10.024

Massé F (2016) The political ecology of human-wildlife conflict: producing wilderness, insecurity, and displacement in the Limpopo National Park. Conserv Soc 14:100-111

Mills MGL, Juritz JM, Zucchini W (2001) Estimating the size of spotted hyena (Crocuta Crocuta) populations through playback recordings allowing for non-response. Anim Conserv 4:335-343

Naidoo R, Fisher B, Manica A, Balmford A (2016) Estimating economic losses to tourism in African from the illegal killing of elephants. Nat Commun 7:13379. https://doi.org/10.1038/ncomms13379

Packer C, Herbst L, Pusey AE et al (1988) Reproductive success of lions. In: Clutton-Brock TH (ed) Reproductive success: studies of individual variation in contrasting breeding systems. University of Chicago Press, Chicago, pp 363-383

Packer C, Kosmala M, Cooley HS et al (2009) Sport hunting, predator control and conservation of large carnivores. PLoS ONE 4:e5941

Pennycuick CJ, Rudnai J (1970) A method of identifying individuals lion with an analysis of the reliability of identification. J Zool. https://doi.org/10.1111/j.1469-7998.1970.tb03093.x

Raza RH, Chauhan DS, Pasha MKS, Sinha S (2012) Illuminating the blind spot: a study on illegal trade in Leopard parts in India (2001-2010). TRAFFIC/WWF India, New Delhi

Riggio J, Andrew J, Dollar L et al (2013) The size of savannah Africa: a lion's (Panthera leo) view. Biodivers Conserv 22:17-35

Ripple WJ, Estes JA, Beschta RL et al (2014) Status and ecological effects of the world's largest carnivores. Science 343:1241484

Rosen GE, Smith KF (2010) Summarizing the evidence on international trade in illegal wildlife. EcoHealth 7:24-32

Stalmans M, Peel M (2012) Parque Nacional de Banhine, Moçambique wildlife survey November 2012. Technical report

Stalmans M, Gertenbach WPD, Carvalho-Serfontein F (2004) Plant communities and landscapes of the Parque Nacional do Limpopo, Mozambique. Koedoe 47:61-81

Swanepoel LH, Balme G, Williams S, Power RJ, Synman A, Gaigher I, Senekal C, Martins Q, Child MF (2016) A conservation assessment of Panthera pardus. Red List of Mammals of South Africa, Swaziland and Lesotho

Verheij P (2019) An assessment of wildlife poaching and trafficking in Boliva and Suriname. IUCN NL, Amsterdam

Whitman K, Starfield AM, Quadling HS, Packer C (2004) Sustainable trophy hunting of African lions. Nature 428(11):175-178

Williams VL, Sas-Rofes M (2019) Born captive: a survey of the lion breeding, keeping and hunting industries in South Africa. PLoS ONE 14(5):e0217409

Williams V L, Newton D, Loveridge A, Macdonald DW (2015) Bones of contention: an assessment of the South African trade in African Lion bones and other body parts. TRAFFIC, Cambridge, UK \& WildCru, Oxford, UK

Williams VL, Loveridge AJ, Newton DJ, Macdonald DW (2017a) A roaring trade? The legal trade in Panthera leo bones from Africa to east-southeast Asia. PLoS ONE 12:e0185996

Williams VL, Loveridge AJ, Newton DJ, Macdonald DW (2017b) Questionnaire survey of the pan-African trade in lion body parts. PLoS ONE 12(10):e0187060. https://doi.org/10.1371/journal.pone.0187060

Wyler L, Sheikh P (2008) International illegal trade in wildlife: threats and U.S. policy. CRS Report for Congress. p 3

Publisher's Note Springer Nature remains neutral with regard to jurisdictional claims in published maps and institutional affiliations. 


\section{Affiliations}

\section{K. T. Everatt ${ }^{1,2,3,4} \cdot$ R. Kokes $^{3} \cdot$ C. Lopez Pereira ${ }^{5}$}

1 Panthera, New York, NY, USA

2 Center for African Conservation Ecology, Department of Zoology, Nelson Mandela University, Port Elizabeth 6031, South Africa

3 Greater Limpopo Carnivore Programme, Limpopo National Park, Mozambique

4 Centre for Wildlife Management, University of Pretoria, Pretoria, South Africa

5 Administração Nacional das Áreas de Conservação, Maputo, Mozambique 